\title{
JRAK
}

JURNAL RISET

AKUNTANSI

VOLUME 5 NO 1

JANUARI 2019

DAN BISNIS

jrak@plb.ac.id

\section{MEMPREDIKSI BESARAN ANGSURAN KPR PADA BANK KONVENSIONAL BERDASARKAN PERHITUNGAN ANGSURAN KPR DARI BANK SYARIAH}

Jonathan Lucky Sasmitha dan Budi Harto

\begin{abstract}
ABSTRAK
Studi ini bertujuan untuk memberikan perbandingan besaran angsuran KPR dari bank konvensional dan bank syariah yang harus dibayar oleh nasabah. Data yang diambil menggunakan data akad KPR Mubaharah dari bank syariah sebagai dasar pembanding. Hasil studi ini menunjukkan bahwa pada KPR bank konvensional, besaran angsuran yang harus dibayarkan oleh nasabah dapat berubah-ubah tergantung dari fluktuasi suku bunga. Sementara pada KPR bank syariah, besaran angsuran dari awal sampai dengan akhir masa angsuran jumlahnya tetap karena sudah ditentukan pada awal perjanjian.
\end{abstract}

Kata Kunci : KPR, Suku Bunga, Bank Konvensional, Bank Syariah.

\section{PENDAHULUAN}

\section{Latar Belakang}

Kebutuhan akan perumahan telah menjadi kebutuhan pokok bagi masyarakat. Namun, semakin tingginya harga perumahan dibandingkan dengan pendapatan masyarakat menjadi suatu permasalahan tersendiri dalam pemenuhannya. Peranan lembaga keuangan seperti perbankan dalam hal ini menjadi sangat penting. Dengan adanya fasilitas pembiayaan berupa Kredit Perumahan Rakyat (KPR) bagi masyarakat menjadi solusi bai upaya untuk mempunyai rumah.

Baik itu bank konvensional maupun bank syariah, KPR sudah menjadi salah satu program penyaluran dana ke masyarakat. Namun yang membedakan adalah, KPR pada bank syariah memperlihatkan besaran angsuran yang harus dibayar oleh nasabah sampai dengan masa akhir KPR. Hal ini tidak terlepas dari salah satu asas bank syariah, yaitu transparansi. Sedangkan pada bank konvensional, pada umumnya nasabah hanya diberikan besaran angsuran hanya untuk beberapa tahun pertama, tidak sampai akhir masa KPR. Hal ini dikarenakan pada bank konvensional masih memperhitungkan estimasi perubahan suku bunga dan nilai uang di masa 
mendatang (time value of money). Kondisi ini memberikan ketidakpastian bagi nasabah untuk mengukur kemampuan membayar KPR sampai dengan akhir masanya dikarenakan besaran angsuran sampai dengan akhir periode tidak dapat dipastikan sejak awal.

Berdasarkan hal tersebut, penulis tertarik untuk membuat penelitian dengan judul "Memprediksi Besaran Angsuran KPR dari Bank Konvensional Berdasarkan Angsuran KPR dari Bank Syariah".

\section{LANDASAN TEORI}

\section{Pengertian dan Kegiatan Bank}

Kasmir (2017:12) menjelaskan bahwa bank merupakan perusahaan yang bergerak dalam bidang keuangan. Artinya perbankan selalu berkaitan dengan masalah dalam bidang keuangan. Kegiatan bank umum secara umum terbagi menjadi tiga, yaitu kegiatan penghimpunan dana dari masyarakat (funding), kegiatan penyaluran dana ke masyarakat (lending), dan jasa bank lainnya. Kegiatan penghimpunan dana dari masyarakat dapat berupa simpanan giro, simpanan tabungan, dan simpanan deposito. Kegiatan penyaluran dana ke masyarakat dapat berupa kredit investasi, kredit modal kerja, kredit perdagangan, kredit konsumtif, dan kredit produktif. Kegiatan jasa bank lainnya berupa jasa setoran, jasa pembayaran, jasa penagihan, jasa kliring, jasa penukaran mata uang asing, dan lain-lain.

Berdasarkan prinsip pelaksanaanya, bank dapat dibedakan menjadi bank konvensional dan bank syariah. Keuntungan bagi bank konvensional dihasilkan dari bunga yang telah ditentukan. Dalam hal penyaluran dana kepada masyarakat, bunga bagi bank konvensional dapat diartikan sebagai balas jasa kepada nasabah atas fasilitas produk yang diberikan oleh bank kepada nasabah. Bunga yang diberikan kepada masyarakat merupakan bunga pinjaman yang harus dibayar oleh nasabah.

Faktor-faktor yang menentukan besar kecilnya bunga pinjaman kepada nasabah antara lain dipengaruhi oleh target laba yang ditentukan, jangka waktu, produk yang kompetitif, dan persaingan. Semakin tinggi target laba dan jangka waktu yang diberikan kepada nasabah akan membuat bunga pinjaman menjadi tinggi pula. Namun, keterbalikan dari hal ini, dengan adanya persaingan antar bank yang menawarkan produk sejenis membuat bunga pinjaman menjadi lebih kompetitif untuk ditawarkan kepada masyarakat.

Komponen-komponen yang mempengaruhi penentuan suku bunga kredit antara lain adalah total biaya dana, biaya operasi, cadangan risiko kredit macet, dan laba yang diinginkan. Total biaya dana merupakan total bunga yang dikeluarkan oleh bank untuk memperoleh dana simpanan, baik dalam bentuk simpanan giro, tabungan, maupun deposito. Total biaya dana tergantung dari seberapa bunga yang ditetapkan untuk memperoleh dana yang diinginkan. Semakin besar bunga yang dibebankan terhadap bunga simpanan, semakin tinggi pula biaya dananya. Biaya operasi 
mencakup biaya yang dikeluarkan oleh bank untuk menjalankan operasinya. Yang termasuk biaya operasi antara lain biaya gaji, biaya administrasi, biaya pemeliharaan, dan biaya-biaya lainnya.

Faktor cadangan risiko kredit macet merupakan cadangan terhadap macetnya kredit yang akan diberikan, hal ini disebabkan setiap kredit yang diberikan pasti mengandung suatu risiko yang tidak terbayar. Faktor terakhir adalah seberapa besar laba yang diinginkan oleh bank. Kieso (2011) menjelaskan bahwa besaran bunga pinjaman dipengaruhi oleh estimasi nilai pinjaman, jangka waktu pinjaman, dan target laba yang ingin dihasilkan oleh bank.

\section{Konsep Keuntungan Bagi Bank Syariah}

Menurut Muhamad (2017:5), Bank Syariah adalah bank yang berasaskan, antara lain, pada asas kemitraan, keadilan, transparansi, dan universal serta melakukan kegiatan usaha perbankan berdasarkan prinsip syariah. Karakteristik dari bank syariah antara lain pelarangan riba dalam berbagai bentuknya, tidak mengenal konsep nilai waktu dari uang, konsep uang sebagai alat tukar bukan sebagai komoditas, tidak diperkenankan melakukan kegiatan yang bersifat spekulatif,tidak diperkenankan menggunakan dua harga untuk satu barang, dan tidak diperkenankan dua transaksi dalam satu akad.

Bank syariah beroperasi atas dasar konsep bagi hasil. Bank syariah tidak menggunakan bunga sebagai alat untuk memperoleh pendapatan maupun membebankan bunga atas penggunaan dana pinjaman karena bunga merupakan riba yang diharamkan. Suatu transaksi dianggap sesuai dengan prinsip syariah apabila telah memenuhi seluruh syarat seperti transaksi tidak mengandung unsur kedzaliman, tidak mengandung riba, tidak membahayakan pihak sendiri atau pihak lain, tidak mengandung unsur penipuan, tidak mengandung materi-materi yang diharamkan, dan tidak mengandung unsur judi.

\section{Pembiayaan atas dasar akad Murabahah}

Menurut Muhamad (2017:46), akad Murabahah adalah transaksi jual-beli suatu barang sebesar harga perolehan barang ditambah dengan margin yang disepakati oleh para pihak, di mana penjual menginformasikan terlebih dahulu harga perolehan kepada pembeli. Mekanisme dalam pembiayaan ini adalah antara bank yang bertindak sebagai penyedia dana dalam kegiatan transaksi Murabahah dengan nasabah. Bank memiliki kewajiban menyediakan dana untuk merealisasikan penyediaan barang yang dipesan nasabah dan memberikan potongan dalam besaran yang wajar dengan tanpa diperjanjikan dimuka. Bank dapat membiayai sebagian atau seluruh harga pembelian barang yang telah disepakati kualifikasinya.

Manfaat dari pembiayaan ini bagi bank adalah sebagai salah satu bentuk penyaluran dana dan memperoleh pendapatan dalam bentuk margin. Manfaat bagi nasabah dari pembiayaan ini menjadi salah satu alternatif untuk memperoleh barang tertentu melalui pembiayaan dari bank. Manfaat lain bagi nasabah adalah mendapatkan angsuran pembayaran dengan jumlah angsuran yang tidak akan berubah selama masa perjanjian. 


\section{PEMBAHASAN}

\section{Pelaksanaan Akad Murabahah}

Pelaksanaan Akad Murabahah dihadiri oleh para pihak yang berkepentingan, yaitu pihak bank, pihak nasabah, dan pihak pemerintah yang diwakili oleh notaris yang ditunjuk bank. Pihak notaris akan memberikan Akad Pembiayaan Murabahah yang berisi perjanjian antara pihak bank dan nasabah. Pihak notaris akan membacakan isi akad tersebut dihadapan kedua belah pihak.

Poin-poin utama yang ada di dalam akad tersebut antara lain berisi mengenai pembiayaan, jangka waktu pembayaran, realisasi pembayaran, serta hak dan kewajiban lainnya bagi kedua belah pihak. Poin pembiayaan berisi obyek perjanjian antara kedua belah pihak, misalkan berupa 1 unit rumah. Dalam poin itu juga dijelaskan mengenai harga beli bank, keuntungan yang diperoleh bank, harga beli bank, uang muka, dan sisa kewajiban nasabah. Poin jangka waktu berisi berapa lama jangka waktu pembiayaan yang harus dilunasi oleh nasabah. Poin realisasi pembiayaan berisi syarat-syarat dan ketentuan yang harus dipenuhi oleh nasabah sebelum melakukan perjanjian, antara lain berupa uang muka yang harus sudah dibayarkan oleh nasabah.

\section{Perhitungan Besaran Angsuran KPR Berdasarkan Akad Murabahah}

Dalam salah satu isi perjanjian mengenai KPR perumahan antara bank syariah dan nasabah diperoleh data-data sebagai berikut : Harga beli bank Rp 395.000.000.000, keuntungan bank Rp 354.900.000, harga jual bank Rp 749.900.000, uang muka yang dibayarkan nasabah Rp 70.000.000, sisa kewajiban yang harus dilunasi oleh nasabah sebesar Rp 679.900.000, jangka waktu angsuran selama 180 bulan. Salah satu pelaksanaan prinsip transaparansi dari bank syariah adalah memberikan informasi mengenai berapa jumlah keuntungan yang diinginkan oleh bank dan jumlah yang harus dibayarkan oleh nasabah secara keseluruhan.

Dari data di atas diperoleh keuntungan yang diinginkan oleh bank adalah sebesar Rp 354.900.000 didapat dari harga jual bank Rp 749.900.000 - harga beli bank sebesar Rp 395.000.000. Sementara sisa kewajiban yang harus dilunasi oleh nasabah sebesar Rp 679.900.000 didapat dari harga jual bank Rp 749.900.000. - uang muka yang dibayarkan nasabah sebesar Rp 70.000.000. Perhitungan besaran angsuran per bulan untuk nasabah diperoleh dengan cara membagi sisa kewajiban yang harus dilunasi oleh nasabah dengan jangka waktu pelunasan KPR. Perhitungan angsuran per bulan menjadi Rp 3.777.222 ( Rp 679.900.000 : 180 bulan).

\section{Prediksi Besaran Angsuran KPR Dari Bank Konvensional}

Prediksi besaran angsuran KPR bank konvensional dilakukan berdasarkan data transaksi dari bank syariah, yaitu harga beli rumah Rp 395.000.000, uang muka yang dibayarkan oleh nasabah Rp 70.000.000, pokok pinjaman sebesar $\mathrm{Rp} 325.000 .000$ (Rp 395.000.000-Rp 70.000.000), masa angsuran 180 bulan, dan estimasi bunga pinjaman per tahun. 
Dalam praktiknya, penawaran KPR dari bank konvensional hanya menginformasikan besaran angsuran untuk beberapa tahun pertama menggunakan tingkat suku bunga tertentu (pada umumnya dengan tingkat bunga rendah untuk menarik minat nasabah). Besaran angsuran untuk tahun-tahun berikutnya belum dapat diinformasikan sehubungan dengan kemungkinan fluktuasi suku bunga. Sebagai contoh, bank konvensional akan menawarkan KPR untuk 2 tahun pertama dengan pokok pinjaman sebesar Rp 325.000.000 dan bunga pinjaman promosi sebesar $8 \%$.

Jika keuntungan yang ingin dihasilkan oleh bank adalah sama untuk KPR secara konvensional maupun syariah, maka keuntungannya adalah sebesar Rp 679.900.000. Jika diasumsikan bunga pinjaman sebesar $8 \%$ adalah tetap (flat) selama 180 bulan, maka besaran angsuran per bulan adalah sebesar Rp 3.105.869, dan total pembayaran dari nasabah selama 180 bulan adalah sebesar Rp 559.056.469. Terdapat selisih sebesar Rp 120.843.531 dari total pembayaran yang diterima dari bank syariah (Rp 679.900.000 - Rp 559.056.469).

Dengan asumsi bahwa bank konvensional dan bank syariah mendapatkan keuntungan yang sama sampai dengan akhir mas angsuran, maka ilustrasi pada tabel 1 tidak dapat dijalankan. Tabel 1 mengilustrasikan bahwa tarif bunga tetap (flat) sebesar $8 \%$ selama 180 bulan. Pada pelaksanaannya, bank konvensional hanya memberikan perhitungan besaran angsuran untuk beberapa tahun pertama, menggunakan asumsi besaran bunga sebesar x \%. Pada ilustrasi berikutnya, diasumsikan bahwa bank konvensional memberikan promosi suku bunga sebesar 10 $\%$ hanya untuk 2 tahun pertama seperti terdapat dalam tabel 2.

Tabel 2 mengilustrasikan bahwa jika bank konvensional memberikan promosi diskon sebesar $10 \%$ selama 2 tahun pertama, maka besaran angsuran yang harus dibayar oleh nasabah adalah sebesar Rp 3.492.467 untuk setiap bulannya. Untuk mendapatkan keuntungan yang diinginkan sebelumnya, maka setelah tahun kedua, bank harus menaikkan lagi suku bunga kreditnya. Diasumsikan setelah tahun kedua, bank menaikkan suku bunga kredit menjadi $11 \%$. Dampaknya adalah kenaikan besaran angsuran bagi nasabah menjadi Rp 3.674.048. Jika dijumlahkan secara keseluruhan, maka total pembayaran yang akan diterima oleh bank pada akhir masa angsuran adalah sebesar Rp 656.970.689. Hasil ini masih lebih kecil dibandingkan penerimaan pada bank syariah sebesar Rp 679.900.000. Konsekuensinya adalah agar mendapatkan hasil yang sesuai dengan penerimaan pada bank syariah, maka harus ada kenaikan suku bunga kredit lagi oleh bank konvensional.

Tabel 3 mengilustrasikan peningkatan bunga KPR secara bertahap. Untuk 2 tahun pertama, bank menetapkan bunga KPR sebesar $10 \%$. Kemudian untuk tahun kedua dan ketiga, bunga KPR ditingkatkan dinaikkan menjadi $11 \%$. Lalu setelah tahun ketiga, suku bunga KPR dinaikkan kembali menjadi 11,5\%. Dari kenaikan bertahap suku bunga ini, memberikan dampak kenaikan besaran angsuran untuk nasabah. Untuk tahun pertama sampai tahun kedua, besaran angsuran nasabah sebesar Rp 3.492.467 per bulan. Untuk tahun ketiga dan keempat, besaran angsuran nasabah naik menjadi Rp 3.674.048 per bulan. Untuk tahun kelima sampai seterusnya, besaran angsuran nasabah menjadi Rp 3.921.863 per bulan. Sampai dengan akhir masa angsuran, bank 
akan menerima penerimaan sebesar Rp 689.682.247. Jika dibandingkan dengan penerimaan dari bank syariah sebesar Rp 679.900.000, maka terdapat selisih sebesar Rp 9.782.247. 
Tabel 2

\begin{tabular}{|c|c|c|c|c|c|}
\hline Bulan & Angsuran & Angsuran & Total & Saldo & Bulan \\
\hline Bulan & Pokok & Bunga & Angsuran & Pinjaman & Bulan \\
\hline & & & & 325.000 .000 & 91 \\
\hline 1 & 784.133 & 2.708 .333 & 3.492 .467 & 324.215 .867 & 92 \\
\hline 2 & 790.668 & 2.701 .799 & 3.492 .467 & 323.425 .199 & 93 \\
\hline 3 & 797.257 & 2.695 .210 & 3.492 .467 & 322.627 .942 & 94 \\
\hline 4 & 803.900 & 2.688 .566 & 3.492 .467 & 321.824 .042 & 95 \\
\hline 5 & 810.600 & 2.681 .867 & 3.492 .467 & 321.013 .442 & 96 \\
\hline 6 & 817.355 & 2.675 .112 & 3.492 .467 & 320.196 .088 & 97 \\
\hline 7 & 824.166 & 2.668 .301 & 3.492 .467 & 319.371 .922 & 98 \\
\hline 8 & 831.034 & 2.661 .433 & 3.492 .467 & 318.540 .888 & 99 \\
\hline 9 & 837.959 & 2.654 .507 & 3.492 .467 & 317.702 .929 & 100 \\
\hline 10 & 844.942 & 2.647 .524 & 3.492 .467 & 316.857 .986 & 101 \\
\hline 11 & 851.983 & 2.640 .483 & 3.492 .467 & 316.006 .003 & 102 \\
\hline 12 & 859.083 & 2.633 .383 & 3.492 .467 & 315.146 .920 & 103 \\
\hline 13 & 866.242 & 2.626 .224 & 3.492 .467 & 314.280 .677 & 104 \\
\hline 14 & 873.461 & 2.619 .006 & 3.492 .467 & 313.407 .216 & 105 \\
\hline 15 & 880.740 & 2.611 .727 & 3.492 .467 & 312.526 .477 & 106 \\
\hline 16 & 888.079 & 2.604 .387 & 3.492 .467 & 311.638 .397 & 107 \\
\hline 17 & 895.480 & 2.596 .987 & 3.492 .467 & 310.742 .917 & 108 \\
\hline 18 & 902.942 & 2.589 .524 & 3.492 .467 & 309.839 .975 & 109 \\
\hline 19 & 910.467 & 2.582 .000 & 3.492 .467 & 308.929 .508 & 110 \\
\hline 20 & 918.054 & 2.574 .413 & 3.492 .467 & 308.011 .454 & 111 \\
\hline 21 & 925.705 & 2.566 .762 & 3.492 .467 & 307.085 .749 & 112 \\
\hline 22 & 933.419 & 2.559 .048 & 3.492 .467 & 306.152 .331 & 113 \\
\hline 23 & 941.197 & 2.551 .269 & 3.492 .467 & 305.211 .134 & 114 \\
\hline 24 & 949.041 & 2.543 .426 & 3.492 .467 & 304.262 .093 & 115 \\
\hline 25 & 884.979 & 2.789 .069 & 3.674 .048 & 303.377 .114 & 116 \\
\hline 26 & 893.091 & 2.780 .957 & 3.674 .048 & 302.484 .023 & 117 \\
\hline 27 & 901.278 & 2.772 .770 & 3.674 .048 & 301.582 .745 & 118 \\
\hline 28 & 909.540 & 2.764 .508 & 3.674 .048 & 300.673 .206 & 119 \\
\hline 29 & 917.877 & 2.756 .171 & 3.674 .048 & 299.755 .329 & 120 \\
\hline 30 & 926.291 & 2.747 .757 & 3.674 .048 & 298.829 .038 & 121 \\
\hline 31 & 934.782 & 2.739 .266 & 3.674 .048 & 297.894 .256 & 122 \\
\hline 32 & 943.351 & 2.730 .697 & 3.674 .048 & 296.950 .905 & 123 \\
\hline 33 & 951.998 & 2.722 .050 & 3.674 .048 & 295.998 .907 & 124 \\
\hline 34 & 960.725 & 2.713 .323 & 3.674 .048 & 295.038 .183 & 125 \\
\hline 35 & 969.531 & 2.704 .517 & 3.674 .048 & 294.068 .651 & 126 \\
\hline 36 & 978.419 & 2.695 .629 & 3.674 .048 & 293.090 .233 & 127 \\
\hline 37 & 987.388 & 2.686 .660 & 3.674 .048 & 292.102 .845 & 128 \\
\hline 38 & 996.439 & 2.677 .609 & 3.674 .048 & 291.106 .406 & 129 \\
\hline 39 & 1.005 .573 & 2.668 .475 & 3.674 .048 & 290.100 .834 & 130 \\
\hline 40 & 1.014 .790 & 2.659 .258 & 3.674 .048 & 289.086 .044 & 131 \\
\hline 41 & 1.024 .093 & 2.649 .955 & 3.674 .048 & 288.061 .951 & 132 \\
\hline 42 & 1.033 .480 & 2.640 .568 & 3.674 .048 & 287.028 .471 & 133 \\
\hline 43 & 1.042 .954 & 2.631 .094 & 3.674 .048 & 285.985 .517 & 134 \\
\hline 44 & 1.052 .514 & 2.621 .534 & 3.674 .048 & 284.933 .003 & 135 \\
\hline 45 & 1.062 .162 & 2.611 .886 & 3.674 .048 & 283.870 .841 & 136 \\
\hline 46 & 1.071 .899 & 2.602 .149 & 3.674 .048 & 282.798 .942 & 137 \\
\hline 47 & 1.081 .724 & 2.592 .324 & 3.674 .048 & 281.717 .218 & 138 \\
\hline 48 & 1.091 .640 & 2.582 .408 & 3.674 .048 & 280.625 .578 & 139 \\
\hline 49 & 1.101 .647 & 2.572 .401 & 3.674 .048 & 279.523 .931 & 140 \\
\hline 50 & 1.111 .745 & 2.562 .303 & 3.674 .048 & 278.412 .185 & 141 \\
\hline 51 & 1.121 .936 & 2.552 .112 & 3.674 .048 & 277.290 .249 & 142 \\
\hline 52 & 1.132 .221 & 2.541 .827 & 3.674 .048 & 276.158 .028 & 143 \\
\hline 53 & 1.142 .599 & 2.531 .449 & 3.674 .048 & 275.015 .429 & 144 \\
\hline 54 & 1.153 .073 & 2.520 .975 & 3.674 .048 & 273.862 .356 & 145 \\
\hline 55 & 1.163 .643 & 2.510 .405 & 3.674 .048 & 272.698 .713 & 146 \\
\hline 56 & 1.174 .310 & 2.499 .738 & 3.674 .048 & 271.524 .403 & 147 \\
\hline 57 & 1.185 .074 & 2.488 .974 & 3.674 .048 & 270.339 .328 & 148 \\
\hline 58 & 1.195 .938 & 2.478 .111 & 3.674 .048 & 269.143 .391 & 149 \\
\hline 59 & 1.206 .900 & 2.467 .148 & 3.674 .048 & 267.936 .491 & 150 \\
\hline 60 & 1.217 .964 & 2.456 .084 & 3.674 .048 & 266.718 .527 & 151 \\
\hline 61 & 1.229 .128 & 2.444 .920 & 3.674 .048 & 265.489 .399 & 152 \\
\hline 62 & 1.240 .395 & 2.433 .653 & 3.674 .048 & 264.249 .004 & 153 \\
\hline 63 & 1.251 .765 & 2.422 .283 & 3.674 .048 & 262.997 .238 & 154 \\
\hline 64 & 1.263 .240 & 2.410 .808 & 3.674 .048 & 261.733 .998 & 155 \\
\hline 65 & 1.274 .820 & 2.399 .228 & 3.674 .048 & 260.459 .179 & 156 \\
\hline 66 & 1.286 .506 & 2.387 .542 & 3.674 .048 & 259.172 .673 & 157 \\
\hline 67 & 1.298 .299 & 2.375 .750 & 3.674 .048 & 257.874 .375 & 158 \\
\hline 68 & 1.310 .200 & 2.363 .848 & 3.674 .048 & 256.564 .175 & 159 \\
\hline 69 & 1.322 .210 & 2.351 .838 & 3.674 .048 & 255.241 .965 & 160 \\
\hline 70 & 1.334 .330 & 2.339 .718 & 3.674 .048 & 253.907 .635 & 161 \\
\hline 71 & 1.346 .561 & 2.327 .487 & 3.674 .048 & 252.561 .074 & 162 \\
\hline 72 & 1.358 .905 & 2.315 .143 & 3.674 .048 & 251.202 .169 & 163 \\
\hline 73 & 1.371 .361 & 2.302 .687 & 3.674 .048 & 249.830 .808 & 164 \\
\hline 74 & 1.383 .932 & 2.290 .116 & 3.674 .048 & 248.446 .875 & 165 \\
\hline 75 & 1.396 .618 & 2.277 .430 & 3.674 .048 & 247.050 .257 & 166 \\
\hline 76 & 1.409 .421 & 2.264 .627 & 3.674 .048 & 245.640 .836 & 167 \\
\hline 77 & 1.422 .340 & 2.251 .708 & 3.674 .048 & 244.218 .496 & 168 \\
\hline 78 & 1.435 .378 & 2.238 .670 & 3.674 .048 & 242.783 .118 & 169 \\
\hline 79 & 1.448 .536 & 2.225 .512 & 3.674 .048 & 241.334 .581 & 170 \\
\hline 80 & 1.461 .814 & 2.212 .234 & 3.674 .048 & 239.872 .767 & 171 \\
\hline 81 & 1.475 .214 & 2.198 .834 & 3.674 .048 & 238.397 .553 & 172 \\
\hline 82 & 1.488 .737 & 2.185 .311 & 3.674 .048 & 236.908 .816 & 173 \\
\hline 83 & 02.384 & 664 & .048 & .406 .432 & 174 \\
\hline 84 & 1.516 .156 & 2.157 .892 & 3.674 .048 & 233.890 .276 & 175 \\
\hline 85 & 1.530 .054 & 2.143 .994 & 3.674 .048 & 232.360 .222 & 176 \\
\hline 86 & 1. & & & & 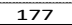 \\
\hline 87 & 1.558 .233 & 2.115 .815 & 3.674 .048 & 229.257 .910 & 178 \\
\hline 88 & 1.572 .517 & 2.101 .531 & 3.674 .048 & 227.685 .392 & 179 \\
\hline 89 & 1. & 2.0 & 48 & 226 & 180 \\
\hline 90 & 1.601 .479 & 2.072 .569 & 3.674 .048 & 224.496 .982 & \\
\hline
\end{tabular}


Tabel 3

\begin{tabular}{|c|c|c|c|c|c|c|}
\hline Bulan & $\begin{array}{c}\text { Angsuran } \\
\text { Pokok }\end{array}$ & $\begin{array}{c}\text { Angsuran } \\
\text { Bunga }\end{array}$ & $\begin{array}{c}\text { Total } \\
\text { Angsuran }\end{array}$ & $\begin{array}{c}\text { Saldo } \\
\text { Pinjaman }\end{array}$ & Bulan & $\begin{array}{c}\text { Angsuran } \\
\text { Pokok }\end{array}$ \\
\hline & & & & 325.000 .000 & 91 & 1.543 .289 \\
\hline 1 & 784.133 & 2.708 .333 & 3.492 .467 & 324.215 .867 & 92 & 1.559 .365 \\
\hline 2 & 790.668 & 2.701 .799 & 3.492 .467 & 323.425 .199 & 93 & 1.575 .608 \\
\hline 3 & 797.257 & 2.695 .210 & 3.492 .467 & 322.627 .942 & 94 & 1.592 .021 \\
\hline 4 & 803.900 & 2.688 .566 & 3.492 .467 & 321.824 .042 & 95 & 1.608 .605 \\
\hline 5 & 810.600 & 2.681 .867 & 3.492 .467 & 321.013 .442 & 96 & 1.625 .361 \\
\hline 6 & 817.355 & 2.675 .112 & 3.492 .467 & 320.196 .088 & 97 & 1.642 .292 \\
\hline 7 & 824.166 & 2.668 .301 & 3.492 .467 & 319.371 .922 & 98 & 1.659 .399 \\
\hline 8 & 831.034 & 2.661 .433 & 3.492 .467 & 318.540 .888 & 99 & 1.676 .684 \\
\hline 9 & 837.959 & 2.654 .507 & 3.492 .467 & 317.702 .929 & 100 & 1.694 .150 \\
\hline 10 & 844.942 & 2.647 .524 & 3.492 .467 & 316.857 .986 & 101 & 1.711 .797 \\
\hline 11 & 851.983 & 2.640 .483 & 3.492 .467 & 316.006 .003 & 102 & 1.729 .628 \\
\hline 12 & 859.083 & 2.633 .383 & 3.492 .467 & 315.146 .920 & 103 & 1.747 .645 \\
\hline 13 & 866.242 & 2.626 .224 & 3.492 .467 & 314.280 .677 & 104 & 1.765 .850 \\
\hline 14 & 873.461 & 2.619 .006 & 3.492 .467 & 313.407 .216 & 105 & 1.784 .244 \\
\hline 15 & 880.740 & 2.611 .727 & 3.492 .467 & 312.526 .477 & 106 & 1.802 .830 \\
\hline 16 & 888.079 & 2.604 .387 & 3.492 .467 & 311.638 .397 & 107 & 1.821 .610 \\
\hline 17 & 895.480 & 2.596 .987 & 3.492 .467 & 310.742 .917 & 108 & 1.840 .585 \\
\hline 18 & 902.942 & 2.589 .524 & 3.492 .467 & 309.839 .975 & 109 & 1.859 .757 \\
\hline 19 & 910.467 & 2.582 .000 & 3.492 .467 & 308.929 .508 & 110 & 1.879 .130 \\
\hline 20 & 918.054 & 2.574 .413 & 3.492 .467 & 308.011 .454 & 111 & 1.898 .704 \\
\hline 21 & 925.705 & 2.566 .762 & 3.492 .467 & 307.085 .749 & 112 & 1.918 .482 \\
\hline 22 & 933.419 & 2.559 .048 & 3.492 .467 & 306.152 .331 & 113 & 1.938 .467 \\
\hline 23 & 941.197 & 2.551 .269 & 3.492 .467 & 305.211 .134 & 114 & 1.958 .659 \\
\hline 24 & 949.041 & 2.543 .426 & 3.492 .467 & 304.262 .093 & 115 & 1.979 .062 \\
\hline 25 & 884.979 & 2.789 .069 & 3.674 .048 & 303.377 .114 & 116 & 1.999 .677 \\
\hline 26 & 893.091 & 2.780 .957 & 3.674 .048 & 302.484 .023 & 117 & 2.020 .507 \\
\hline 27 & 901.278 & 2.772 .770 & 3.674 .048 & 301.582 .745 & 118 & 2.041 .554 \\
\hline 28 & 909.540 & 2.764 .508 & 3.674 .048 & 300.673 .206 & 119 & 2.062 .820 \\
\hline 29 & 917.877 & 2.756 .171 & 3.674 .048 & 299.755 .329 & 120 & 2.084 .308 \\
\hline 30 & 926.291 & 2.747 .757 & 3.674 .048 & 298.829 .038 & 121 & 2.106 .019 \\
\hline 31 & 934.782 & 2.739 .266 & 3.674 .048 & 297.894 .256 & 122 & 2.127 .957 \\
\hline 32 & 943.351 & 2.730 .697 & 3.674 .048 & 296.950 .905 & 123 & 2.150 .123 \\
\hline 33 & 951.998 & 2.722 .050 & 3.674 .048 & 295.998 .907 & 124 & 2.172 .520 \\
\hline 34 & 960.725 & 2.713 .323 & 3.674 .048 & 295.038 .183 & 125 & 2.195 .151 \\
\hline 35 & 969.531 & 2.704 .517 & 3.674 .048 & 294.068 .651 & 126 & 2.218 .017 \\
\hline 36 & 978.419 & 2.695 .629 & 3.674 .048 & 293.090 .233 & 127 & 2.241 .121 \\
\hline 37 & 987.388 & 2.686 .660 & 3.674 .048 & 292.102 .845 & 128 & 2.264 .466 \\
\hline 38 & 996.439 & 2.677 .609 & 3.674 .048 & 291.106 .406 & 129 & 2.288 .054 \\
\hline 39 & 1.005 .573 & 2.668 .475 & 3.674 .048 & 290.100 .834 & 130 & 2.311 .888 \\
\hline 40 & 1.014 .790 & 2.659 .258 & 3.674 .048 & 289.086 .044 & 131 & 2.335 .970 \\
\hline 41 & 1.024 .093 & 2.649 .955 & 3.674 .048 & 288.061 .951 & 132 & 2.360 .303 \\
\hline 42 & 1.033 .480 & 2.640 .568 & 3.674 .048 & 287.028 .471 & 133 & 2.384 .890 \\
\hline 43 & 1.042 .954 & 2.631 .094 & 3.674 .048 & 285.985 .517 & 134 & 2.409 .733 \\
\hline 44 & 1.052 .514 & 2.621 .534 & 3.674 .048 & 284.933 .003 & 135 & 2.434 .834 \\
\hline 45 & 1.062 .162 & 2.611 .886 & 3.674 .048 & 283.870 .841 & 136 & 2.460 .197 \\
\hline 46 & 1.071 .899 & 2.602 .149 & 3.674 .048 & 282.798 .942 & 137 & 2.485 .824 \\
\hline 47 & 1.081 .724 & 2.592 .324 & 3.674 .048 & 281.717 .218 & 138 & 2.511 .718 \\
\hline 48 & 1.091 .640 & 2.582 .408 & 3.674 .048 & 280.625 .578 & 139 & 2.537 .882 \\
\hline 49 & 998.680 & 2.923 .183 & 3.921 .863 & 279.626 .898 & 140 & 2.564 .318 \\
\hline 50 & 1.009 .083 & 2.912 .780 & 3.921 .863 & 278.617 .816 & 141 & 2.591 .029 \\
\hline 51 & 1.019 .594 & 2.902 .269 & 3.921 .863 & 277.598 .222 & 142 & 2.618 .019 \\
\hline 52 & 1.030 .215 & 2.891 .648 & 3.921 .863 & 276.568 .007 & 143 & 2.645 .290 \\
\hline 53 & 1.040 .946 & 2.880 .917 & 3.921 .863 & 275.527 .061 & 144 & 2.672 .846 \\
\hline 54 & 1.051 .789 & 2.870 .074 & 3.921 .863 & 274.475 .272 & 145 & 2.700 .688 \\
\hline 55 & 1.062 .745 & 2.859 .117 & 3.921 .863 & 273.412 .526 & 146 & 2.728 .820 \\
\hline 56 & 1.073 .816 & 2.848 .047 & 3.921 .863 & 272.338 .710 & 147 & 2.757 .245 \\
\hline 57 & 1.085 .001 & 2.836 .862 & 3.921 .863 & 271.253 .709 & 148 & 2.785 .966 \\
\hline 58 & 1.096 .303 & 2.825 .559 & 3.921 .863 & 270.157 .406 & 149 & 2.814 .987 \\
\hline 59 & 1.107 .723 & 2.814 .140 & 3.921 .863 & 269.049 .683 & 150 & 2.844 .310 \\
\hline 60 & 1.119 .262 & 2.802 .601 & 3.921 .863 & 267.930 .421 & 151 & 2.873 .938 \\
\hline 61 & 1.130 .921 & 2.790 .942 & 3.921 .863 & 266.799 .500 & 152 & 2.903 .875 \\
\hline 62 & 1.142 .701 & 2.779 .161 & 3.921 .863 & 265.656 .798 & 153 & 2.934 .123 \\
\hline 63 & 1.154 .605 & 2.767 .258 & 3.921 .863 & 264.502 .194 & 154 & 2.964 .687 \\
\hline 64 & 1.166 .632 & 2.755 .231 & 3.921 .863 & 263.335 .562 & 155 & 2.995 .569 \\
\hline 65 & 1.178 .784 & 2.743 .079 & 3.921 .863 & 262.156 .778 & 156 & 3.026 .773 \\
\hline 66 & 1.191 .063 & 2.730 .800 & 3.921 .863 & 260.965 .715 & 157 & 3.058 .302 \\
\hline 67 & 1.203 .470 & 2.718 .393 & 3.921 .863 & 259.762 .245 & 158 & 3.090 .159 \\
\hline 68 & 1.216 .006 & 2.705 .857 & 3.921 .863 & 258.546 .239 & 159 & 3.122 .348 \\
\hline 69 & 1.228 .673 & 2.693 .190 & 3.921 .863 & 257.317 .566 & 160 & 3.154 .873 \\
\hline 70 & 1.241 .472 & 2.680 .391 & 3.921 .863 & 256.076 .094 & 161 & 3.187 .736 \\
\hline 71 & 1.254 .404 & 2.667 .459 & 3.921 .863 & 254.821 .691 & 162 & 3.220 .942 \\
\hline 72 & 1.267 .470 & 2.654 .393 & 3.921 .863 & 253.554 .221 & 163 & 3.254 .493 \\
\hline 73 & 1.280 .673 & 2.641 .190 & 3.921 .863 & 252.273 .548 & 164 & 3.288 .394 \\
\hline 74 & 1.294 .013 & 2.627 .849 & 3.921 .863 & 250.979 .534 & 165 & 3.322 .648 \\
\hline 75 & 1.307 .493 & 2.614 .370 & 3.921 .863 & 249.672 .042 & 166 & 3.357 .259 \\
\hline 76 & 1.321 .112 & 2.600 .750 & 3.921 .863 & 248.350 .929 & 167 & 3.392 .231 \\
\hline 77 & 1.334 .874 & 2.586 .989 & 3.921 .863 & 247.016 .055 & 168 & 3.427 .566 \\
\hline 78 & 1.348 .779 & 2.573 .084 & 3.921 .863 & 245.667 .276 & 169 & 3.463 .270 \\
\hline 79 & 1.362 .829 & 2.559 .034 & 3.921 .863 & 244.304 .447 & 170 & 3.499 .346 \\
\hline 80 & 1.377 .025 & 2.544 .838 & 3.921 .863 & 242.927 .423 & 171 & 3.535 .798 \\
\hline 81 & 1.391 .369 & 2.530 .494 & 3.921 .863 & 241.536 .054 & 172 & 3.572 .629 \\
\hline 82 & 1.405 .862 & 2.516 .001 & 3.921 .863 & 240.130 .191 & 173 & 3.609 .844 \\
\hline 83 & 1.420 .507 & 2.501 .356 & 3.921 .863 & 238.709 .685 & 174 & 3.647 .446 \\
\hline 84 & 1.435 .304 & 2.486 .559 & 3.921 .863 & 237.274 .381 & 175 & 3.685 .440 \\
\hline 85 & 1.450 .255 & 2.471 .608 & 3.921 .863 & 235.824 .126 & 176 & 3.723 .830 \\
\hline 86 & 1.465 .362 & 2.456 .501 & 3.921 .863 & 234.358 .765 & 177 & 3.762 .620 \\
\hline 87 & 1.480 .626 & 2.441 .237 & 3.921 .863 & 232.878 .139 & 178 & 3.801 .814 \\
\hline 88 & 1.496 .049 & 2.425 .814 & 3.921 .863 & 231.382 .090 & 179 & 3.841 .417 \\
\hline 89 & 1.511 .633 & 2.410 .230 & 3.921 .863 & 229.870 .458 & 180 & 3.881 .431 \\
\hline 90 & 1.527 .379 & 2.394 .484 & 3.921 .863 & 228.343 .079 & & 352.967 .656 \\
\hline
\end{tabular}


Tabel

\begin{tabular}{|c|c|c|c|c|c|c|}
\hline Bulan & $\begin{array}{c}\text { Angsuran } \\
\text { Pokok }\end{array}$ & $\begin{array}{c}\text { Angsuran } \\
\text { Bunga }\end{array}$ & $\begin{array}{c}\text { Total } \\
\text { Angsuran }\end{array}$ & $\begin{array}{c}\text { Saldo } \\
\text { Pinjaman }\end{array}$ & Bulan & $\begin{array}{c}\text { Angsuran } \\
\text { Pokok }\end{array}$ \\
\hline & & & & 325.000 .000 & 91 & 1.707 .935 \\
\hline 1 & 939.203 & 2.166 .667 & 3.105 .869 & 324.060 .797 & 92 & 1.719 .321 \\
\hline 2 & 945.464 & 2.160 .405 & 3.105 .869 & 323.115 .333 & 93 & 1.730 .783 \\
\hline 3 & 951.767 & 2.154 .102 & 3.105 .869 & 322.163 .566 & 94 & 1.742 .321 \\
\hline 4 & 958.112 & 2.147 .757 & 3.105 .869 & 321.205 .454 & 95 & 1.753 .937 \\
\hline 5 & 964.500 & 2.141 .370 & 3.105 .869 & 320.240 .955 & 96 & 1.765 .630 \\
\hline 6 & 970.930 & 2.134 .940 & 3.105 .869 & 319.270 .025 & 97 & 1.777 .401 \\
\hline 7 & 977.402 & 2.128 .467 & 3.105 .869 & 318.292 .623 & 98 & 1.789 .250 \\
\hline 8 & 983.918 & 2.121 .951 & 3.105 .869 & 317.308 .704 & 99 & 1.801 .178 \\
\hline 9 & 990.478 & 2.115 .391 & 3.105 .869 & 316.318 .226 & 100 & 1.813 .186 \\
\hline 10 & 997.081 & 2.108 .788 & 3.105 .869 & 315.321 .145 & 101 & 1.825 .274 \\
\hline 11 & 1.003 .728 & 2.102 .141 & 3.105 .869 & 314.317 .417 & 102 & 1.837 .443 \\
\hline 12 & 1.010 .420 & 2.095 .449 & 3.105 .869 & 313.306 .997 & 103 & 1.849 .692 \\
\hline 13 & 1.017 .156 & 2.088 .713 & 3.105 .869 & 312.289 .841 & 104 & 1.862 .024 \\
\hline 14 & 1.023 .937 & 2.081 .932 & 3.105 .869 & 311.265 .904 & 105 & 1.874 .437 \\
\hline 15 & 1.030 .763 & 2.075 .106 & 3.105 .869 & 310.235 .141 & 106 & 1.886 .933 \\
\hline 16 & 1.037 .635 & 2.068 .234 & 3.105 .869 & 309.197 .506 & 107 & 1.899 .513 \\
\hline 17 & 1.044 .553 & 2.061 .317 & 3.105 .869 & 308.152 .953 & 108 & 1.912 .176 \\
\hline 18 & 1.051 .516 & 2.054 .353 & 3.105 .869 & 307.101 .437 & 109 & 1.924 .924 \\
\hline 19 & 1.058 .526 & 2.047 .343 & 3.105 .869 & 306.042 .911 & 110 & 1.937 .757 \\
\hline 20 & 1.065 .583 & 2.040 .286 & 3.105 .869 & 304.977 .327 & 111 & 1.950 .675 \\
\hline 21 & 1.072 .687 & 2.033 .182 & 3.105 .869 & 303.904 .640 & 112 & 1.963 .680 \\
\hline 22 & 1.079 .838 & 2.026 .031 & 3.105 .869 & 302.824 .802 & 113 & 1.976 .771 \\
\hline 23 & 1.087 .037 & 2.018 .832 & 3.105 .869 & 301.737 .765 & 114 & 1.989 .950 \\
\hline 24 & 1.094 .284 & 2.011 .585 & 3.105 .869 & 300.643 .481 & 115 & 2.003 .216 \\
\hline 25 & 1.101 .579 & 2.004 .290 & 3.105 .869 & 299.541 .901 & 116 & 2.016 .571 \\
\hline 26 & 1.108 .923 & 1.996 .946 & 3.105 .869 & 298.432 .978 & 117 & 2.030 .014 \\
\hline 27 & 1.116 .316 & 1.989 .553 & 3.105 .869 & 297.316 .662 & 118 & 2.043 .548 \\
\hline 28 & 1.123 .758 & 1.982 .111 & 3.105 .869 & 296.192 .904 & 119 & 2.057 .172 \\
\hline 29 & 1.131 .250 & 1.974 .619 & 3.105 .869 & 295.061 .654 & 120 & 2.070 .886 \\
\hline 30 & 1.138 .792 & 1.967 .078 & 3.105 .869 & 293.922 .862 & 121 & 2.084 .692 \\
\hline 31 & 1.146 .384 & 1.959 .486 & 3.105 .869 & 292.776 .479 & 122 & 2.098 .590 \\
\hline 32 & 1.154 .026 & 1.951 .843 & 3.105 .869 & 291.622 .452 & 123 & 2.112 .580 \\
\hline 33 & 1.161 .720 & 1.944 .150 & 3.105 .869 & 290.460 .733 & 124 & 2.126 .664 \\
\hline 34 & 1.169 .464 & 1.936 .405 & 3.105 .869 & 289.291 .269 & 125 & 2.140 .842 \\
\hline 35 & 1.177 .261 & 1.928 .608 & 3.105 .869 & 288.114 .008 & 126 & 2.155 .114 \\
\hline 36 & 1.185 .109 & 1.920 .760 & 3.105 .869 & 286.928 .898 & 127 & 2.169 .482 \\
\hline 37 & 1.193 .010 & 1.912 .859 & 3.105 .869 & 285.735 .889 & 128 & 2.183 .945 \\
\hline 38 & 1.200 .963 & 1.904 .906 & 3.105 .869 & 284.534 .925 & 129 & 2.198 .505 \\
\hline 39 & 1.208 .970 & 1.896 .900 & 3.105 .869 & 283.325 .955 & 130 & 2.213 .161 \\
\hline 40 & 1.217 .030 & 1.888 .840 & 3.105 .869 & 282.108 .926 & 131 & 2.227 .916 \\
\hline 41 & 1.225 .143 & 1.880 .726 & 3.105 .869 & 280.883 .783 & 132 & 2.242 .769 \\
\hline 42 & 1.233 .311 & 1.872 .559 & 3.105 .869 & 279.650 .472 & 133 & 2.257 .720 \\
\hline 43 & 1.241 .533 & 1.864 .336 & 3.105 .869 & 278.408 .939 & 134 & 2.272 .772 \\
\hline 44 & 1.249 .810 & 1.856 .060 & 3.105 .869 & 277.159 .130 & 135 & 2.287 .924 \\
\hline 45 & 1.258 .142 & 1.847 .728 & 3.105 .869 & 275.900 .988 & 136 & 2.303 .176 \\
\hline 46 & 1.266 .529 & 1.839 .340 & 3.105 .869 & 274.634 .458 & 137 & 2.318 .531 \\
\hline 47 & 1.274 .973 & 1.830 .896 & 3.105 .869 & 273.359 .486 & 138 & 2.333 .988 \\
\hline 48 & 1.283 .473 & 1.822 .397 & 3.105 .869 & 272.076 .013 & 139 & 2.349 .548 \\
\hline 49 & 1.292 .029 & 1.813 .840 & 3.105 .869 & 270.783 .984 & 140 & 2.365 .211 \\
\hline 50 & 1.300 .643 & 1.805 .227 & 3.105 .869 & 269.483 .341 & 141 & 2.380 .979 \\
\hline 51 & 1.309 .314 & 1.796 .556 & 3.105 .869 & 268.174 .027 & 142 & 2.396 .853 \\
\hline 52 & 1.318 .042 & 1.787 .827 & 3.105 .869 & 266.855 .985 & 143 & 2.412 .832 \\
\hline 53 & 1.326 .829 & 1.779 .040 & 3.105 .869 & 265.529 .155 & 144 & 2.428 .917 \\
\hline 54 & 1.335 .675 & 1.770 .194 & 3.105 .869 & 264.193 .481 & 145 & 2.445 .110 \\
\hline 55 & 1.344 .579 & 1.761 .290 & 3.105 .869 & 262.848 .901 & 146 & 2.461 .411 \\
\hline 56 & 1.353 .543 & 1.752 .326 & 3.105 .869 & 261.495 .358 & 147 & 2.477 .820 \\
\hline 57 & 1.362 .567 & 1.743 .302 & 3.105 .869 & 260.132 .791 & 148 & 2.494 .339 \\
\hline 58 & 1.371 .651 & 1.734 .219 & 3.105 .869 & 258.761 .140 & 149 & 2.510 .968 \\
\hline 59 & 1.380 .795 & 1.725 .074 & 3.105 .869 & 257.380 .345 & 150 & 2.527 .708 \\
\hline 60 & 1.390 .000 & 1.715 .869 & 3.105 .869 & 255.990 .345 & 151 & 2.544 .559 \\
\hline 61 & 1.399 .267 & 1.706 .602 & 3.105 .869 & 254.591 .078 & 152 & 2.561 .523 \\
\hline 62 & 1.408 .595 & 1.697 .274 & 3.105 .869 & 253.182 .483 & 153 & 2.578 .600 \\
\hline 63 & 1.417 .986 & 1.687 .883 & 3.105 .869 & 251.764 .497 & 154 & 2.595 .790 \\
\hline 64 & 1.427 .439 & 1.678 .430 & 3.105 .869 & 250.337 .057 & 155 & 2.613 .095 \\
\hline 65 & 1.436 .956 & 1.668 .914 & 3.105 .869 & 248.900 .102 & 156 & 2.630 .516 \\
\hline 66 & 1.446 .535 & 1.659 .334 & 3.105 .869 & 247.453 .566 & 157 & 2.648 .053 \\
\hline 67 & 1.456 .179 & 1.649 .690 & 3.105 .869 & 245.997 .388 & 158 & 2.665 .707 \\
\hline 68 & 1.465 .887 & 1.639 .983 & 3.105 .869 & 244.531 .501 & 159 & 2.683 .478 \\
\hline 69 & 1.475 .659 & 1.630 .210 & 3.105 .869 & 243.055 .842 & 160 & 2.701 .368 \\
\hline 70 & 1.485 .497 & 1.620 .372 & 3.105 .869 & 241.570 .345 & 161 & 2.719 .377 \\
\hline 71 & 1.495 .400 & 1.610 .469 & 3.105 .869 & 240.074 .944 & 162 & 2.737 .506 \\
\hline 72 & 1.505 .370 & 1.600 .500 & 3.105 .869 & 238.569 .575 & 163 & 2.755 .756 \\
\hline 73 & 1.515 .405 & 1.590 .464 & 3.105 .869 & 237.054 .169 & 164 & 2.774 .128 \\
\hline 74 & 1.525 .508 & 1.580 .361 & 3.105 .869 & 235.528 .661 & 165 & 2.792 .622 \\
\hline 75 & 1.535 .678 & 1.570 .191 & 3.105 .869 & 233.992 .983 & 166 & 2.811 .240 \\
\hline 76 & 1.545 .916 & 1.559 .953 & 3.105 .869 & 232.447 .067 & 167 & 2.829 .981 \\
\hline 77 & 1.556 .222 & 1.549 .647 & 3.105 .869 & 230.890 .845 & 168 & 2.848 .848 \\
\hline 78 & 1.566 .597 & 1.539 .272 & 3.105 .869 & 229.324 .248 & 169 & 2.867 .840 \\
\hline 79 & 1.577 .041 & 1.528 .828 & 3.105 .869 & 227.747 .207 & 170 & 2.886 .959 \\
\hline 80 & 1.587 .555 & 1.518 .315 & 3.105 .869 & 226.159 .652 & 171 & 2.906 .205 \\
\hline 81 & 98.138 & 7.731 & 05.869 & 224.561 .514 & 172 & 2.925 .580 \\
\hline 82 & 1.608 .793 & 1.497 .077 & 3.105 .869 & 222.952 .721 & 173 & 2.945 .084 \\
\hline 83 & 9.518 & 1.486 .351 & 5.869 & 221.333 .204 & 174 & 2.964 .718 \\
\hline 84 & 1.630 .315 & 1.475 .555 & 3.105 .869 & 219.702 .889 & 175 & 2.984 .483 \\
\hline 85 & 1.641 .183 & 1.464 .686 & 3.105 .869 & 218.061 .706 & 176 & 3.004 .379 \\
\hline 86 & 1.652 .125 & 1.453 .745 & 3.105 .869 & 216.409 .581 & 177 & 3.024 .408 \\
\hline 87 & 1.663 .139 & 1.442 .731 & 3.105 .869 & 214.746 .442 & 178 & 3.044 .571 \\
\hline 88 & 1.674 .226 & 1.431 .643 & 3.105 .869 & 213.072 .216 & 179 & 3.064 .868 \\
\hline 8 & 1.685 .388 & 1.420 .481 & 3.105 .869 & 211.386 .828 & 180 & 3.085 .301 \\
\hline 90 & 1.696 .624 & 1.409 .246 & 3.105 .869 & 209.690 .205 & & 325.000 .000 \\
\hline
\end{tabular}




\section{Kesimpulan}

Berdasarkan data penelitian yang penulis buat bahwa Memprediksi Besaran Angsuran KPR dari Bank Konvensional Berdasarkan Angsuran KPR dari Bank Syariah perlu telaah yang lebih dalam, baik dalam implementasi maupun evaluasi proses pelaksanaannya. Terdapat persamaan dalam pelaksanaan antara angsuran KPR Bank Konvensional maupun KPR Bank Syariah sehingga penilaian variabel penilaian pelaksanaan pun memiliki kesamaan seperti syarat pengajuan kredit, prosedur pemberian kredit.

\section{DAFTAR PUSTAKA}

Juhaya S. Pradja. 2013. Manajemen Perbankan Syariah.Pustaka Setia Bandung Kieso, Donald E., Weygandt, Jerry J., Warfield, Terry D. 2011. Intermediate Accounting. Wiley. Kasmir. 2017. Manajemen Perbankan. Jakarta : Raja Grafindo Persada. Muhamad. 2017. Manajemen Dana Bank Syariah. Jakarta : Raja Grafindo Persada.

Undang-undang Republik Indonesia Nomor 10 tentang Perbankan tahun 1998 Tentang Perbankan. Undang-undang Republik Indonesia Nomor 21 Tahun 2008 Tentang Perbankan Syariah. 